\title{
University of Arkansas at Little Rock instihutes student library fee
}

$\mathbf{F}$ iscal 1991-1992 marks the first year the Ottenheimer Library at the University of Arkansas at Little Rock (UALR) will receive supplemental budget support from a student fee which became operating procedure this past July.

In slightly more than 20 years, UALR has grown from less than 5,000 undergraduate students to over 12,000 undergraduate and graduate students. These graduate programs include doctoral work which the North Central Accrediting Association sanctioned this year.

That kind of growth can have several effects on the university's library. Budgets do not increase very rapidly and grants cannot supplement all new programs. In fact, with state support evolving from a legislature that only meets every two years, the biennial financial preparations always lag behind the demands placed upon the library and its staff.

In the spring of 1987 the University of Arkansas Board of Trustees passed a list of fees which the Little Rock campus hoped to institute the following fall. This list included expanded fees of many kinds: for laboratory use, for music instruction, for the use of physical education facilities, and for foreign language instruction, to mention a few. Also instituted at approximately the same time was a user fee charged to library patrons who were not connected to the university. These fees were designed to generate general revenues at a more rapid pace so that the institution could meet its expanded programmatic needs by means other than the normal budget process.

In 1989 and 1990 the library director put forward to central administration the idea of a student library fee. This fee would be used immediately for materials, technology, and services that have a direct impact upon student needs. The fee was passed by the University of Arkansas System Board in the spring of 1991 ; it requires that $\$ 1.50$ per semester credit hour be collected, then transferred to the library for purchases to benefit students. Revenues will be adjusted each year as enrollment grows, and the $\$ 1.50$ can be increased.

Approximately $\$ 350,000$ was generated during 1991-92, and is expected to grow as enrollment surges; UALR is projected to reach $18,000-20,000$ students by the year 2000 . The library administration has publicly stated that monies raised will be used to buy monographs, videocassettes, reference materials, music, compact discs, and equipment.

Students' reactions to the required library fee are very positive. Gayla Marie Tyler, a senior who plans to attend graduate school at UALR, said, "I can understand and appreciate the library fee. Our money will benefit all students, especially those like myself who intend to go on to higher studies." Robert Austin and Tracy Ahring both commented that now the library can expand its book collection with recent publications that will update the holdings. Carson Baxter, another student, said, "This fee will be put to better use than some others; we can be at tip-top standard now."-Don Sweet, library director; Katby Sanders, assistant director, public services; and Bill Traylor, assistant director, technical services, University of Ankansas, Little Rock (Bitnet: BATAYLOR@UALR.Edu)
Week (NLW) celebration. The University of South Alabama Biomedical Library held drawings during this year's NLW. Prizes awarded included copicards for $\$ 5.00$ worth of photocopying and free computer searches (value up to $\$ 20.00$ ). The Northeastern Ohio Universities College of Medicine (NEOUCOM) celebrated NLW with "The Second Annual Great NEOUCOM Read Aloud" and "The Faculty Match Game" in which NEOUCOM students and faculty had the chance to match faculty members with their favorite books.

\section{Auburn dedicates library addition}

On November 8, 1991, the 207,000-square-foot addition to the Auburn University Libraries was dedicated. The addition doubled the library's size increasing the building's capacity to 2.5 million volumes with seating for 2,500 . State and university bonds as well as private sup- 